\title{
「男性のための料理講座」参加者の食に対する 意識・行動に関する調查
}

\author{
斉藤由紀子*1，武安 眞珠 ${ }^{*}$, 及川 正文*2，㴰本 秀美*1 \\ *1国立研究開発法人医薬基盤・健康 · 栄養研究所 国立健康 · 栄養研究所 \\ *2公益財団法人調布ゆうあい福祉公社
}

\begin{abstract}
【目的】東京都下で20年以上開催されてきた「男性のための料理講座」参加者の食に対する意識・行動を把握し今後の講座運営に資す るため, 講座終了時質問紙調査結果の分析を行った。

【方法】平成19〜28年に公益財団法人 C 福祉公社主催生きがい介護予防講座「男性のための料理講座」に参加し, 講座終了時質問紙に 回答した87名の結果を分析した。本講座では年 5 回栄養の講話と調理実習を行っている。質問紙では「参加の動機」「家庭での調理の 有無」「「講座の献立」「「食意識の变化」「満足度」「実施回数」に関する調査を行った。

【結果】「参加の動機」では「料理技術の習得」28名,「退職後の仲間づくり」12名が上位を占めた。「講座の献立」は,「良かった」と 「大变だった」と回答した献立名が共通していた。「家庭での調理の有無」では, 講座の献立を作ってみた者が45名であった。参加の前 後で食意識が変化したと回答した者が54名であり, それらの内容は料理への興味や調理技術, 調理に対する気持ちであった。料理講座 に満足していた者は63名であった。

【結論】参加の動機から積極的な参加者が多く, 大変だが充実感のある献立を望んでいると考えられた。また講座終了時の調査結果か ら, 半数近くが家庭で調理をしており料理や調理技術への興味が高まったことが推察された。高齢者男性向けの料理講座は参加者に とつて食事の自立へつながる可能性が示唆された。
\end{abstract}

栄養学䧱誌, Vol.77 No.5 123-132 (2019)

キーワード：高齢者男性, 料理講座, 食の自立, 介護予防

\section{I .はじめに}

我が国の, 人口の高齢化は著しく「65歳以上」の老年 人口割合は $26.6 \%$ であり, 老年人口は 2015 年の 3,387 万人 から， 2020年には 3,619 万人へと増加することが予測され ている1)。平成28年国民生活基礎調査によれば，65歳以 上の者のいる世帯は全世帯の $48.4 \%$ に達しており, その 内訳をみると「夫婦のみの世帯」が $31.1 \%$ で最も多く, 次いで「単独世帯」が27.1\%である2)。高齢者夫婦世帯 では食事作りは女性が担当していることが多いと推定さ れるが3)，高齢者男性でも $13.3 \%$ が単独世帯であり 2$)$, 自 身で食事作りを担う男性の割合が今後増加すると考えら れる。単独世帯の後期高齢者の男女 20 名を対象とした先 行研究4) では $90 \%$ が食事を自分で作っており, ほぼ全員 が「若い時からの食事作りの習慣」をあげていた。河野 らの先行研究では, 都市高層住宅地域の一人暮らしの高 齢男性における日常生活の維持に関する「弱み」とし て，「食事内容が偏っている」や「食べることについての 問題が多い」といった問題点が指摘されている5)。今後 は，高齢者男性における食の自立の必要性がますます高 まると推察される。
食育基本法が施行されてから 10 年以上が経過し, 平成 28 (2016）年から 5 年間の第 3 次食育推進基本計画6) が 示され, さらに各都道府県でも具体的な数值目標を掲げ た食育推進計画が策定，実施されている。東京都は，平 成28年（2016）度から 5 年間の食育推進基本計画を公表 している。その中で「生涯にわたり健全な食生活を実践 するための食育の推進」を掲げており, 施策の方向とし ては「低栄養を予防する健康的な食生活の支援」や「人 や地域とつながる社会参加の促進」を行うとしている77。 こうした中，各地で地域での高齢者男性の食の自立支援 を目的とした料理教室の取り組みや8, 9), 高齢者男女を対 象とした介入研究では料理教室参加による栄養改善効果 が報告されている10)。しかし，高齢者男性に料理教室に 参加を促すためには, 彼らが教室に期待することや参加 の動機に関する分析が必要であるが，これを行った実践 的な報告はみられない。

そこで, 我々は高齢者男性の食の自立の取り組みとし て, 東京都下で20年以上運営されてきた男性向けの料理 教室である「男性のための料理講座」に着目した。参加 者の講座終了時の質問紙調査結果を用い, 今後の講座の 充実のための資料作成のための分析を行ったので，ここ

連絡先：瀧本秀美 $=162-8636$ 東京都新宿区戸山1-23-1 国立研究開発法人医薬基盤・健康 · 栄養研究所 国立健康・栄養研究所 電話 03-3203-5721 FAX 03-3202-3278 E-mail thidemi@nibiohn.go.jp 
に報告する。

\section{II. 事業・活動内容}

\section{1. 事業の内容}

公益財団法人 C 福祉公社（以下：C 福祉公社）では, 平成 2 （1990）年より「生きがい講座」として男性の家 庭料理コースを開始した。おおむね50歳以上の男性を対 象とした簡単な家庭料理を学ぶ講座で, 平成22（2010） 年より名称は「生きがい講座 男性のための料理講座」 から「生きがい介護予防講座 男性のための料理講座」 （以下：「男性のための料理講座」）と変更され，平成30 （2018）年度まで継続されている。この「男性のための料 理講座」は, C 福祉公社主催の他の「生きがい介護予防 講座」事業（フォークダンスやパソコンなど）の中で最 も歴史のある講座である。毎年 8 月頃より C 市の広報な どを通じて参加を呼びかけ，参加費用は計 $5,000 ６, 000$ 円で先着12名まで募集している。平成 2 (1990) 年第 1 回目の講座は 6 回コースで, 1 回 4 時間半のコース, 参 加費は全 6 回で2, 000円であった。講師には栄養士を迎 え, 大根一本をまるごと使った料理を作った。その後修 了生が中心となり翌平成 3 （1991）年より「だいこんの 会」という自主グループができた。現在の「男性のため の料理講座」の会場は C 市市民プラザの調理室を利用 し, 年一回計 5 回のコースで行っている（写真 1 )。平成 19 （2007）年度からは, 参加の動機や終了後の感想を把 握する目的で，無記名自記式の質問紙調査が開始され た。平成19２3（2007～2011）年度講座の各回における テーマと献立名は表 1 に示したとおりである。平成 24 （2012）年度から担当者らが交代したことで, 各回のテー マと献立名, 質問紙内容が変更され, 献立の栄養価計算
結果が算出された（表 2 )。ただし受講者のテキストには エネルギーと食塩相当量のみ示している。

\section{2. 自主グループ「だいこんの会」}

本講座修了者で自主グループ「だいこんの会」を運営 している。「だいこんの会」は，毎月第 2 土曜日に定例会 を「男性のための料理講座」の会場と同じ C 市市民プラ ザで開いている。発足当初は「男性のための料理講座」 講師が献立を立てていたが, 現在では会員自身で献立を 立て，食材の買い物から調理まで行っている。献立には 講座で学習した主食, 主菜, 副菜, 汁物やデザートまで が並び，季節行事も取り入れられているだけではなく， 講師も年に数回参加し, 交流を図っている。本会の現在 の会員数は20名ほどであり，平成26（2013）年内閣府 「エイジレスライフ章・社会参加章」を受章した。

\section{3. 対象と方法}

平成19年から28（2007～2016）年までに C 福祉公社主 催の生きがい介護予防講座「男性のための料理講座」に 参加した94名中，講座終了時の質問紙調査に回答した 87 名の結果を分析対象とした。

\section{4. 倫理的配慮}

平成19年から27（2007～2015）年度までの参加者に対 しては, C 福祉公社のホームページにて本研究への協力 依頼とオプトインの確認を行い，平成28（2016）年度参 加者には担当者と講師の管理栄養士（著者：斉藤）から 口頭で質問紙調査結果を研究に用いる旨を説明し，研究 協力への了承を得た。質問紙調査は無記名での実施であ り，回答結果から個人は特定不能である。本研究は国立 研究開発法人医薬基盤 - 健康 - 栄養研究所国立健康 - 栄 養研究所の研究倫理審査委員会の承認を得て実施した (承認番号【健栄58】)。

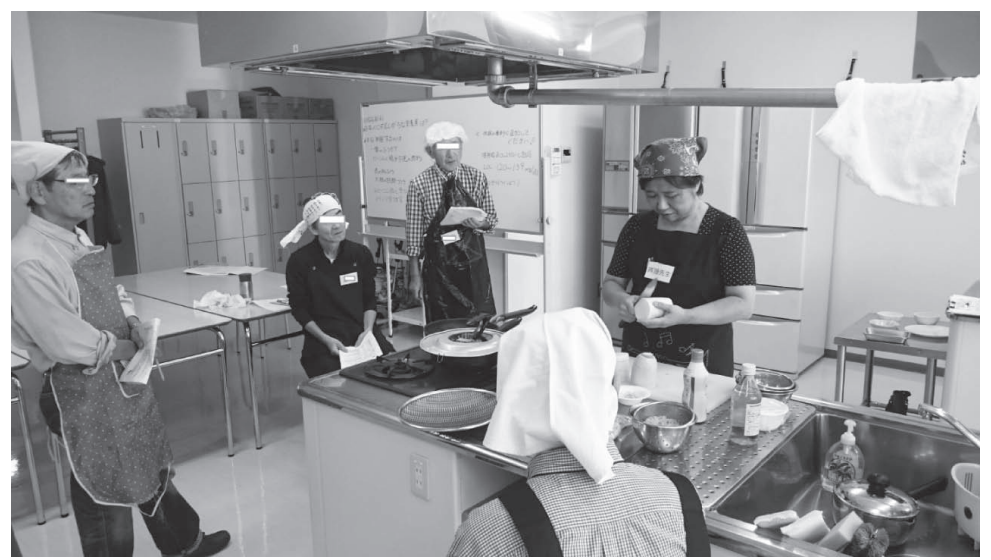

写真 1 料理講座の様子

調理のデモストレーションを行っているのが講師（第一著者） 


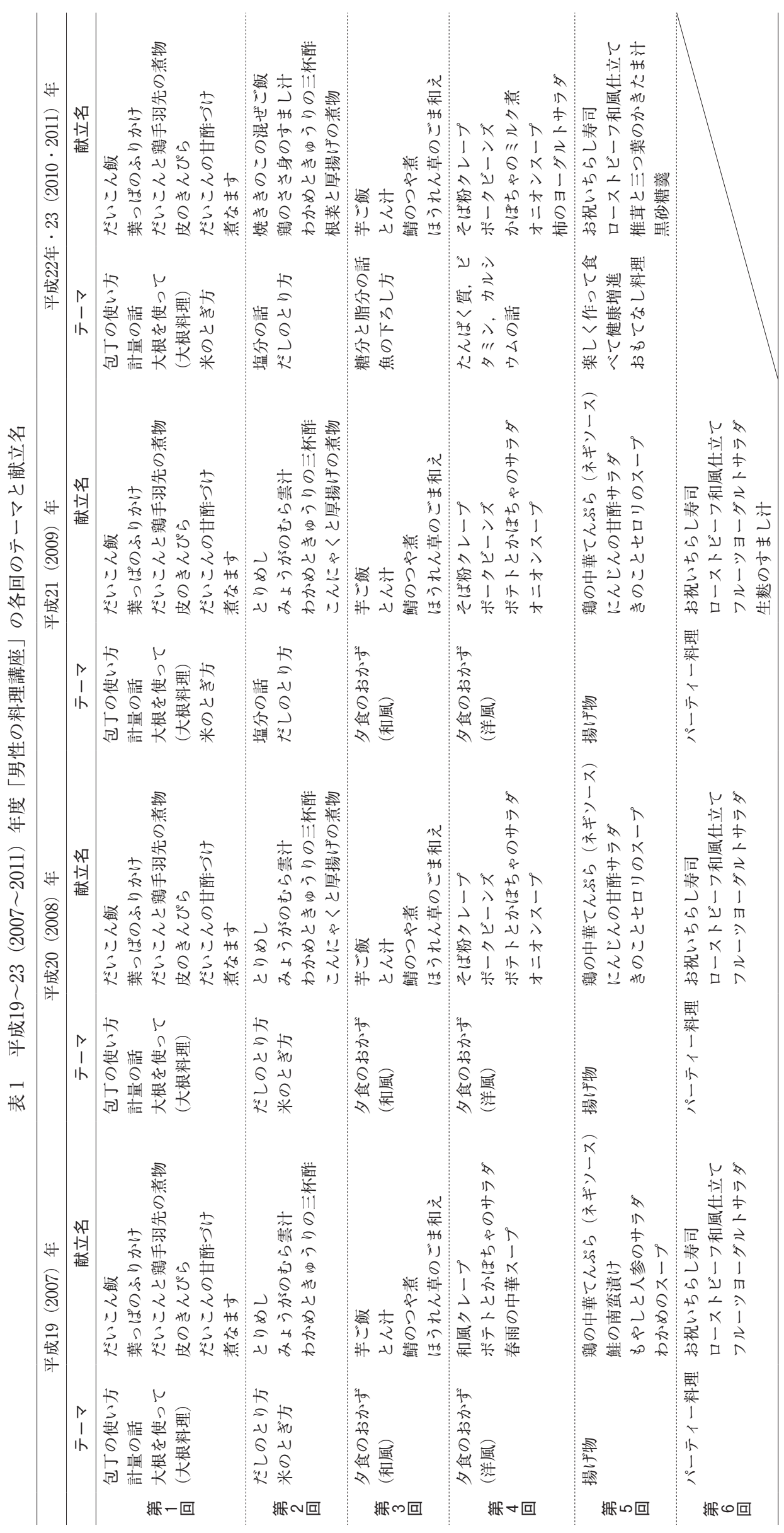




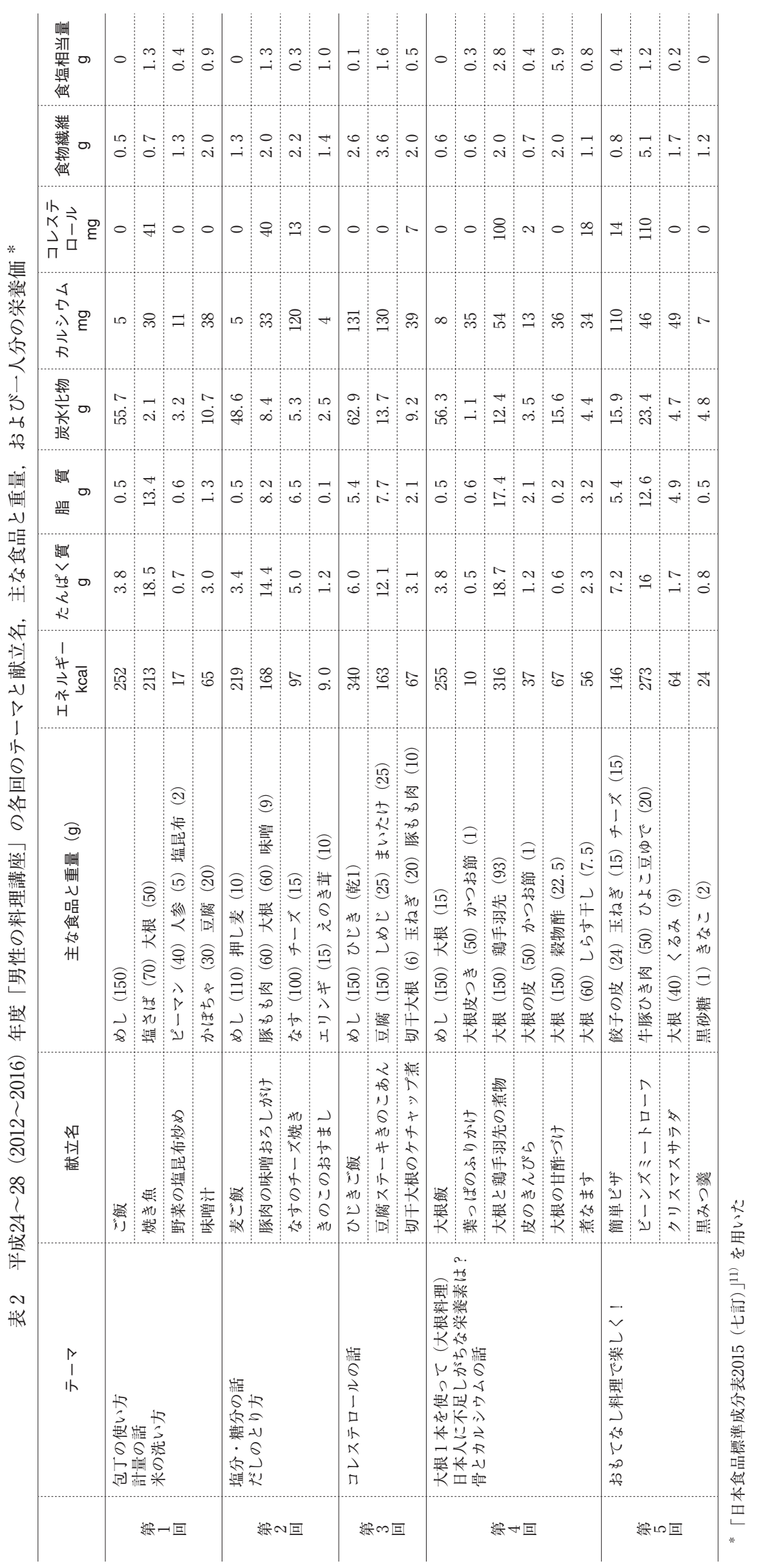




\section{III. 事業・活動成果}

1. 質問紙調查全般の結果について

各調査年度に扔ける質問紙の内容と，それぞれに対す
る回答の集計結果を表 3 に示した。回答者数は設問に よって異なっている場合があった。

「講座（コース）の実施回数に対する評価」については 『ちょうど良い』と回答した者が87名中 63 名と最も多く，

表 3 実施年度別質問紙調査の結果

\begin{tabular}{|c|c|c|c|c|c|c|c|c|c|c|c|}
\hline 実施年度 & $\begin{array}{l}\text { 平成19 } \\
\text { (2007) }\end{array}$ & $\begin{array}{c}20 \\
(2008)\end{array}$ & $\begin{array}{c}21 \\
(2009)\end{array}$ & $\begin{array}{c}22 \\
(2010)\end{array}$ & $\begin{array}{c}23 \\
(2011)\end{array}$ & $\begin{array}{c}24 \\
(2012)\end{array}$ & $\begin{array}{c}25 \\
(2013)\end{array}$ & $\begin{array}{c}26 \\
(2014)\end{array}$ & $\begin{array}{c}27 \\
(2015)\end{array}$ & $\begin{array}{c}28 \\
(2016)\end{array}$ & 総計 \\
\hline 参加者数 & 12 & 7 & 12 & 12 & 12 & 12 & 10 & 5 & 7 & 5 & 94 \\
\hline 回答者数 & 11 & 6 & 12 & 12 & 8 & 12 & 10 & 5 & 6 & 5 & 87 \\
\hline \multicolumn{12}{|l|}{ 実施回数に対する評価 } \\
\hline 多い & 0 & 0 & 0 & 0 & 0 & 0 & 0 & 0 & 0 & 0 & 0 \\
\hline ちょうどよい & 5 & 5 & 11 & 6 & 4 & 11 & 8 & 5 & 3 & 5 & 63 \\
\hline 少ない & 6 & 1 & 1 & 6 & 4 & 1 & 2 & 0 & 3 & 0 & 24 \\
\hline \multicolumn{12}{|l|}{ 希望実施回数（記入者のみ） } \\
\hline 10以上 & 5 & 0 & 1 & - & 3 & 1 & 1 & 0 & 2 & 0 & 7 \\
\hline $5 \sim 9$ & 1 & 1 & 0 & - & 1 & 0 & 0 & 1 & 1 & 0 & 3 \\
\hline 5 末満 & 0 & 0 & 0 & - & 0 & 1 & 1 & 0 & 0 & 0 & 2 \\
\hline \multicolumn{12}{|l|}{ 参加費 } \\
\hline 高い & 0 & 0 & - & 1 & 0 & 0 & 0 & 0 & 0 & 0 & 1 \\
\hline ちょうどよい & 9 & 4 & - & 7 & 4 & 12 & 10 & 4 & 6 & 5 & 61 \\
\hline 安い & 2 & 2 & - & 3 & 4 & 0 & 0 & 1 & 0 & 0 & 12 \\
\hline \multicolumn{12}{|l|}{ 全 5 回の献立 } \\
\hline とても参考になった & - & - & - & - & - & 11 & 10 & 5 & 5 & 4 & 35 \\
\hline まあまあ参考になった & - & - & - & - & - & 1 & 0 & 0 & 1 & 1 & 3 \\
\hline あまり参考にならなかった & - & - & - & - & - & 0 & 0 & 0 & 0 & 0 & 0 \\
\hline \multicolumn{12}{|l|}{ 良かった献立 ${ }^{\dagger}$} \\
\hline 1 回目 & 1 & 0 & 1 & 1 & 0 & 2 & 0 & 0 & 0 & 0 & 2 \\
\hline 2 回目 & 0 & 2 & 0 & 3 & 0 & 1 & 3 & 1 & 1 & 0 & 11 \\
\hline 3 回目 & 2 & 0 & 3 & 1 & 0 & 1 & 0 & 1 & 3 & 0 & 11 \\
\hline 4 回目 & 1 & 1 & 2 & 3 & 2 & 3 & 2 & 4 & 0 & 1 & 19 \\
\hline 5 回目 & 0 & 0 & 0 & 1 & 3 & 7 & 3 & 2 & 2 & 3 & 21 \\
\hline 6 回目 & 5 & 2 & 5 & 0 & - & - & - & - & - & - & 12 \\
\hline 全て & 0 & 0 & 1 & 0 & 0 & 0 & 1 & 0 & 0 & 0 & 2 \\
\hline \multicolumn{12}{|l|}{ 大変だった献立 ${ }^{\dagger}$} \\
\hline 1 回目 & 0 & 1 & 1 & 1 & 1 & 0 & 0 & 0 & 0 & 0 & 4 \\
\hline 2 回目 & 0 & 0 & 1 & 0 & 0 & 0 & 0 & 0 & 0 & 0 & 1 \\
\hline 3 回目 & 0 & 0 & 3 & 1 & 1 & 1 & 0 & 0 & 1 & 0 & 7 \\
\hline 4 回目 & 4 & 1 & 3 & 1 & 1 & 4 & 5 & 2 & 2 & 0 & 23 \\
\hline 5 回目 & 0 & 1 & 0 & 3 & 4 & 3 & 2 & 2 & 1 & 3 & 19 \\
\hline 6 回目 & 1 & 0 & 2 & 0 & - & - & - & - & - & - & 3 \\
\hline なし & 0 & 1 & 0 & 0 & 0 & 1 & 3 & 2 & 0 & 1 & 8 \\
\hline \multicolumn{12}{|l|}{ 家庭での調理の有無 } \\
\hline あり & - & - & 9 & 7 & 3 & 11 & 7 & 3 & 3 & 2 & 45 \\
\hline なし & - & - & 2 & 0 & 1 & 1 & 1 & 1 & 1 & 3 & 10 \\
\hline \multicolumn{12}{|l|}{ 食意識変化の有無 } \\
\hline あり & - & - & 9 & 10 & 7 & 11 & 8 & 4 & 4 & 2 & 54 \\
\hline なし & - & - & 2 & 0 & 1 & 1 & 1 & 1 & 1 & 3 & 10 \\
\hline \multicolumn{12}{|l|}{ 参加しての満足度 } \\
\hline 満足 & 10 & 5 & 11 & 8 & 6 & 7 & 7 & 5 & 2 & 2 & 63 \\
\hline やや満足 & 1 & 1 & 1 & 3 & 2 & 5 & 3 & 0 & 2 & 3 & 21 \\
\hline やや不満 & 0 & 0 & 0 & 0 & 0 & 0 & 0 & 0 & 1 & 0 & 1 \\
\hline 不満 & 0 & 0 & 0 & 0 & 0 & 0 & 0 & 0 & 0 & 0 & 0 \\
\hline \multicolumn{12}{|l|}{ 参加の動機 ${ }^{\dagger}$} \\
\hline 基礎を学びたい & 4 & 0 & - & 0 & 0 & 0 & 0 & 1 & 1 & 1 & 7 \\
\hline 料理に興味 & 2 & 0 & - & 0 & 0 & 0 & 1 & 0 & 0 & 1 & 4 \\
\hline 料理技術の習得 & 2 & 2 & - & 2 & 5 & 7 & 4 & 1 & 3 & 2 & 28 \\
\hline 妻のすすめ & 3 & 2 & - & 2 & 0 & 0 & 2 & 1 & 1 & 0 & 11 \\
\hline 退職後の仲間づくり & 1 & 2 & - & 2 & 3 & 1 & 0 & 1 & 1 & 1 & 12 \\
\hline 市報を見て & 0 & 1 & - & 0 & 0 & 0 & 2 & 1 & 0 & 0 & 4 \\
\hline その他 & 0 & 0 & - & 0 & 1 & 1 & 1 & 0 & 0 & 0 & 3 \\
\hline \multicolumn{12}{|l|}{ 参加しての感想 ${ }^{\dagger}$} \\
\hline 大変良かった & 1 & 1 & 1 & 2 & 4 & 1 & 2 & 2 & 0 & 1 & 15 \\
\hline 有意義だった & 1 & 2 & 1 & 0 & 3 & 3 & 2 & 2 & 0 & 0 & 14 \\
\hline 今後も参加希望 & 3 & 0 & 1 & 3 & 2 & 3 & 1 & 0 & 5 & 3 & 21 \\
\hline その他 & 2 & 1 & 5 & 3 & 1 & 3 & 5 & 1 & 1 & 1 & 23 \\
\hline
\end{tabular}

† 複数回答あり。

$「$ 一」は該当する質問項目が質問紙になかった場合。

質問項目ごとに回答者数を示したため，回答者数の総計は87名とならない。

平成24年から講師変更により，献立変更が行われた（表 $1 \cdot 2) 。$ 


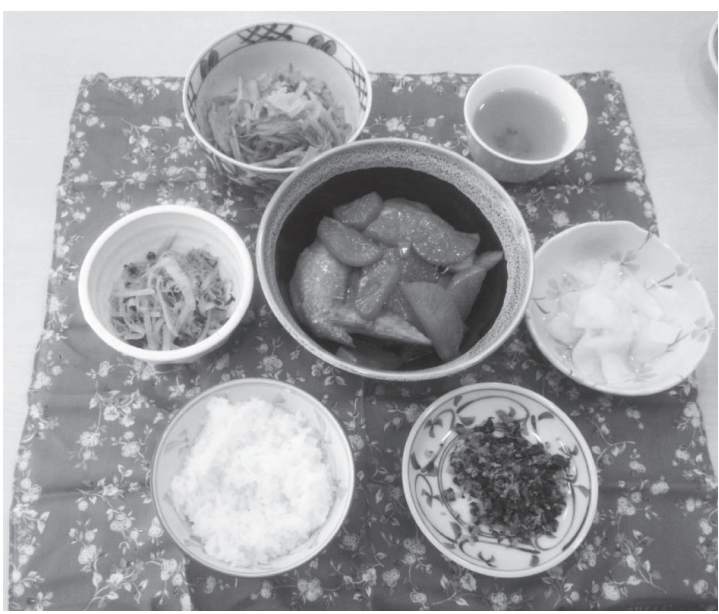

写真 2 大根料理

(上段左 : 皮のきんぴら, 中段左 : 者なます, 中段中 : 大根と鶏 手羽先の煮物, 中段右：大根の甘酢づけ, 下段左 : 大根飯, 下 段右：葉っぱのふりかけ)

『少ない』は24名であった。『多い』と答えた者はいな かった。「少ない」と答えた者のうち,「希望実施回数」 に回答した者では 10 回以上が 7 名, $5 \sim 9$ 回が 3 名, 5 回未満が 2 名であった。「参加費」については, 回答者 74 名中『高い』と答えた者は 1 名, 『ちょうどよい』が 61 名, 『安い』が12名であった。

平成24（2012）年から質問紙に追加された「全 5 回の 献立について参考になったかどうか」に関しては, 回答 者38名中『とても参考になった』35名，『まあまあ参考に なった』3名で，『あまり参考にならなかった』という者 はいなかった。

「取り組んでみて良かった献立」(以下「良かった献 立」) と「大変だった献立」については, 表 2 のと抢り献 立の変更が行われたため, それぞれ結果が分かれた。平 成19年から $23(2007 \sim 2011)$ 年度の第 1 回と平成 24 (2012) 年度からの第 4 回のテーマは同じ『大根料理』 (写真 2 ) である。平成21（2009）年度から設問に追加さ れた「家庭での調理の有無」では，実際に家庭で調理し てみたという者が45名で，実践しなかった者 24 名の約 2 倍であった。同様に平成21（2009）年から設問に追加さ れた「食意識の変化」については，『変化あり』が54名， 『変化なし』が10名であった。具体的な自由記載内容に は, 料理への興味や調理技術の向上, これまで調理を担 当してきた妻への感謝といった, 調理に対する気持ちの 変化を挙げる者が 28 名と多く, 次いで栄養のバランスや 食塩摂取，エネルギーに気をつけるようになったという 栄養に対する意識の変化を挙げた者が15名であった。「参 加しての満足度」では, 『満足』と『やや満足』を合わせ ると86名であり，『不満』と答えたものはいなかった。
複数回答である「参加の動機」では『料理技術の習得』 が一番多く28名，ついで『退職後の仲間づくり』12名， 『妻のすすめ』が11名, 『基礎を学びたい』7名,『料理に 興味があった』4名，『市報を見て』4名であった。「参 加しての感想」では78名が自由記載しており大きく分類 すると『今後も参加を希望』が21名，『大変良かった』が 15名，『有意義だった』が15名であった。

2. 個別の献立に関する結果について（表 4)

平成23年（2011）度までの「良かった献立」と「大変 だった献立」の両方に共通していたのは『㧍祝いちらし 寿司』, 『ローストビーフ和風仕立て』, 『オニオンスープ』 であった。平成24（2012）年度から平成28（2016）年度 では,「良かった献立」は第 5 回のおもてなし料理である 『簡単ピザ』,『ビーンズミートローフ』,『クリスマスサラ ダ』、『黒みつ美』を挙げた者がいずれも14名と多く, 次 いで『大根料理』が 7 名, 『豚肉の味噌おろしがけ』が 5 名であった。「大変だった献立」は『大根料理』12名，第 5 回の抒もてなし料理である『簡単ピザ』,『ビーンズ ミートローフ』，『クリスマスサラダ』，『黒みつ美』がい ずれも 8 名 (うちビーンズミートローフは 4 名), 『豆腐 ステーキ』が 2 名であった。理由の内訳をみると，「良 かった献立」の理由では『美味しかった』をあげた者が 7 名, 『色どり (カラフル)』が 4 名であった。「大変だっ た献立」の理由では『手間がかかる』9名, 『手順が分か らない』9 名, 『品数や材料が多い』が 7 名であった。

参加者が家庭で調理した献立については, 平成21から 23 （2009～2011）年度までは，『大根料理』3 名, 『かほ ちゃのミルク煮』2名,『オニオンスープ』『ポークビー ンズ』『芋ご飯』『鯖のつや煮』1名であった。平成24か ら28（2012２016）年度では, 『野菜の昆布炒め』6 名, 『豆腐ステーキ』と『なすのチーズ焼き』が各 5 名, 『大 根料理』と『みそ汁』が各 4 名であった。これらの献立 をあげた理由は, 『簡単で美味しい』が 3 名, 『手軽で美 味しい』が 3 名, 『美味しかった』が1名であった。

\section{3. 参加者の声について}

各年度から特徴的な回答を表 5 に示した。「次回及び次 のステップが有っても良いと思う」や，「もう少し時間が あったら，素材の購入からやってみたら，少し実践的に なったのではないかと思う」など前向きな意見がみられ た一方，「多くの料理が並行して作られるため，自分の担 当したものしかわからない」「「男の料理は初心者を目的 でお願いします」といった意見も見られた。 
表 4 献立に関する質問紙調查結果

\begin{tabular}{|c|c|c|c|c|c|c|c|}
\hline \multicolumn{8}{|c|}{ 良かった献立 } \\
\hline \multicolumn{4}{|c|}{ 平成19～23（2007～2011）年 } & \multicolumn{4}{|c|}{ 平成24～28（2012～2016）年 } \\
\hline 順位 & 献立名 & 人数 & 理由 & 順位 & 献立名 & 人数 & 理由 \\
\hline \multirow{4}{*}{ 位 } & \multirow[t]{4}{*}{ お祝いちらし寿司 } & \multirow[t]{4}{*}{7} & \multirow{4}{*}{$\begin{array}{l}\text { 祝寿司が作れた（2） } \\
\text { 美味しかった（2） } \\
\text { 色どり良かった（1） } \\
\text { 好きな献立（1） }\end{array}$} & \multirow{4}{*}{ 位 } & 簡単ピザ & 14 & カラフル （3） \\
\hline & & & & & ビーンズミートローフ & 14 & 美味しい（3） \\
\hline & & & & & クリスマスサラダ & 14 & 孫達に腕をふるえる（2） \\
\hline & & & & & 黒みつ美 & 14 & 家族に喜ばれる（2） \\
\hline 位 & $\begin{array}{l}\text { ローストビーフ和風 } \\
\text { 仕立て }\end{array}$ & 5 & 作り方が簡単（1） & 位 & $\begin{array}{l}\text { 大根 } 1 \text { 本を使って } \\
(\text { 大根料理 })^{\dagger}\end{array}$ & 7 & 大根1本を活用できた（3） \\
\hline $\begin{array}{l}3 \\
\text { 位 }\end{array}$ & オニオンスープ & 4 & 作ってみたかった（2） & $\begin{array}{c}3 \\
\text { 位 }\end{array}$ & 豚肉の味増おろしがけ & 5 & $\begin{array}{l}\text { 美味しい (2) } \\
\text { 家で好評（1） }\end{array}$ \\
\hline
\end{tabular}

大変だった献立

\begin{tabular}{|c|c|c|c|c|c|c|c|}
\hline \multicolumn{4}{|c|}{ 平成19～23（2007～2011）年 } & \multicolumn{4}{|c|}{ 平成24～28（2012～2016）年 } \\
\hline 順位 & 献立名 & 人数 & 理由 & 順位 & 献立名 & 人数 & 理由 \\
\hline \multirow{3}{*}{ 位 } & 鯖のつや煮 & 4 & 魚の下ろし方が困難（3） & \multirow{3}{*}{ 位 } & \multirow{3}{*}{$\begin{array}{l}\text { 大根 } 1 \text { 本を使って } \\
(\text { 大根料理) })^{\dagger}\end{array}$} & \multirow[t]{3}{*}{12} & \multirow{3}{*}{$\begin{array}{l}\text { 手順が分からない（5） } \\
\text { 手間がかかり大変（4） }\end{array}$} \\
\hline & そばクレープ & 4 & クレープが難しい（2） & & & & \\
\hline & $\begin{array}{l}\text { ローストビーフ和風 } \\
\text { 仕立て }\end{array}$ & 4 & $\begin{array}{l}\text { 燒き方が難しい (2) } \\
\text { 手間がかかる (2) }\end{array}$ & & & & \\
\hline \multirow{4}{*}{ 位 } & \multirow[t]{4}{*}{ お祝いちらし寿司 } & \multirow[t]{4}{*}{3} & \multirow{4}{*}{$\begin{array}{l}\text { 材料が多い（2） } \\
\text { 下準備が大変（1） }\end{array}$} & \multirow{4}{*}{ 位 } & 簡単ピザ & 8 & 品数が多い（5） \\
\hline & & & & & ビーンズミートローフ & 8 & 加熱時間に戸惑い（1） \\
\hline & & & & & クリスマスサラダ & 8 & 時間的にタイト（1） \\
\hline & & & & & 黒みつ美 & 8 & - \\
\hline \multirow[t]{3}{*}{$\begin{array}{l}3 \\
\text { 位 }\end{array}$} & 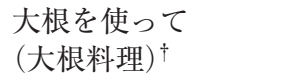 & 2 & 手順が分からない（2） & \multirow[t]{3}{*}{$\begin{array}{l}3 \\
\text { 位 }\end{array}$} & \multirow[t]{3}{*}{ 豆腐ステーキ } & \multirow[t]{3}{*}{2} & \multirow[t]{3}{*}{ 焼き具合に苦労した（1） } \\
\hline & オニオンスープ & 2 & 難しく手間がかかる（3） & & & & \\
\hline & ポークビーンズ & 2 & 根気が必要（2） & & & & \\
\hline
\end{tabular}

家庭で取り組んだ献立

\begin{tabular}{|c|c|c|c|c|c|c|c|}
\hline \multicolumn{4}{|c|}{ 平成21～23（2009～2011） 年 $^{\dagger}$} & \multicolumn{4}{|c|}{ 平成24～28（2012～2016）年 } \\
\hline 順位 & 献立名 & 人数 & 感想 & 順位 & 献立名 & 人数 & 感想 \\
\hline 位 & $\begin{array}{l}\text { 大根を使って } \\
(\text { (大根料理) })^{\dagger}\end{array}$ & 3 & 家族から概ね好評（1） & 位 & 野菜の塩昆布炒め & 6 & 簡単で美味しい（3） \\
\hline \multirow{2}{*}{ 位 } & \multirow[t]{2}{*}{ かぼちゃのミルク煮 } & \multirow[t]{2}{*}{2} & \multirow[t]{2}{*}{-} & \multirow{2}{*}{ 位 } & 豆腐のステーキ & 5 & 良くできた（1） \\
\hline & & & & & なすのチーズ焼き & 5 & 手軽で美味しい（3） \\
\hline \multirow[t]{4}{*}{$\begin{array}{l}3 \\
\text { 位 }\end{array}$} & オニオンスープ & 1 & $\begin{array}{l}\text { 玉ねぎの処理が勉強に } \\
\text { なった (1) }\end{array}$ & \multirow[t]{4}{*}{$\begin{array}{c}3 \\
\text { 位 }\end{array}$} & $\begin{array}{l}\text { 大根 } 1 \text { 本を使って } \\
(\text { 大根料理 })^{\dagger}\end{array}$ & 4 & 美味しかった（1） \\
\hline & ポークビーンズ & 1 & - & & \multirow[t]{3}{*}{ 味増汁 } & \multirow[t]{3}{*}{4} & \multirow[t]{3}{*}{ だしの取り方を実施（2） } \\
\hline & 芋ご飯 & 1 & - & & & & \\
\hline & 鯖のつや煮 & 1 & - & & & & \\
\hline
\end{tabular}

理由, 感想の（）内は回答者の人数

†『大根料理』は大根飯, 葉っぱのふりかけ, 大根と鶏手羽先の煮物, 皮のきんぴら, 大根の甘酢づけ, 者なます（詳細は表 2 に示 した）

‡「家庭での調理の有無」は平成19（2007）年と20（2008）年は質問項目がなかった（表 3 参照）。

$「-」 は$ 理由の欄に未記入者あり。 
表 5 質問紙調查実施年度別の主な参加者の声

\begin{tabular}{|c|c|}
\hline 実施年度 & 自由意見, 要望など \\
\hline $\begin{array}{l}\text { 平成19 } \\
\text { (2007) }\end{array}$ & $\begin{array}{l}\text { · 今後, 中級クラスの開設を検討して頂きたい。 } \\
\text { • 次回及び次のステップが有っても良いと思う。 }\end{array}$ \\
\hline $\begin{array}{c}20 \\
(2008)\end{array}$ & $\begin{array}{l}\text { ・だしのとり方や野菜の切り方をはじめ料理の基礎から学ぶことができ，初期の目的を充分果たすことができた。 } \\
\text { •有意義な会でした。 }\end{array}$ \\
\hline $\begin{array}{c}21 \\
(2009)\end{array}$ & $\begin{array}{l}\text { ·だいこんの会に入会します。 } \\
\text { ·大変有意義でした。ありがとうございました。 }\end{array}$ \\
\hline $\begin{array}{c}22 \\
(2010)\end{array}$ & $\begin{array}{l}\text { •いろいろなレパートリーに取り組みたかったので, もう少し回数があればよかった。 } \\
\text { ·多くの料理が並行して作られるため, 自分の担当したものしかわからない。対応策はないか？ }\end{array}$ \\
\hline $\begin{array}{c}23 \\
(2011)\end{array}$ & $\begin{array}{l}\text { ·人数が手頃で, 先生が手取り教えてくれて勉強になった。これ以上多くなると自分が何をやったのか残らない。 } \\
\text { ·参加された皆さんと楽しくできて本当に良かったした。 }\end{array}$ \\
\hline $\begin{array}{c}24 \\
(2012)\end{array}$ & $\begin{array}{l}\text { ·低料金で, 実際の料理作りが体験でき，貴重な体験ができた。会を重ねる毎に，点として有った知識が線に成っ } \\
\text { た部分が出来ました。 } \\
\text { ·男の料理は初心者を目的でお願いします。 }\end{array}$ \\
\hline $\begin{array}{c}25 \\
(2013)\end{array}$ & $\begin{array}{l}\text { •少し時間がかかっても, 段取りながらやりたい。 } \\
\text { ·講義は, 大変親切丁寧で, 分かりやすかった。もう少し時間があったら, 素材の購入からやってみたら, 少し実 } \\
\text { 践的になったのではないかと思う。 }\end{array}$ \\
\hline $\begin{array}{c}26 \\
(2014)\end{array}$ & $\begin{array}{l}\text { ·今まで } 5 \text { 回ぐらい料理教室に参加したが，先生やスタッフの方を含め } 1 \text { 番良かった。ありがとうございました。 } \\
\text { 他にも男性の料理教臸のコースを増やして欲しい。 } \\
\text { •価值ある講座です。貴重な経験をさせていただきました。 }\end{array}$ \\
\hline $\begin{array}{c}27 \\
(2015)\end{array}$ & $\begin{array}{l}\text { ・講座のネーミングをもう少し考えた方が良いのでは？！「介護予防」は少し気になる。元気が出るネーミングが } \\
\text { 良い。 } \\
\text { •アッという間に終わった。もう少し回数があっても良いかな }\end{array}$ \\
\hline $\begin{array}{c}28 \\
(2016)\end{array}$ & $\begin{array}{l}\text { ・レシピを見ながらでも料理を作る機会を増やして, 自分の作れる料理を増やしていきたい。 } \\
\cdot 1 \text { 講座 } 5 \text { 回程度が良いですが, 年 } 2 \sim 3 \text { 回あったら良いと思います。 }\end{array}$ \\
\hline
\end{tabular}

・参加者の声は質問紙の自由記入欄より抜粋

\section{N. 今後の課題}

表 3 に示したとおり, 平成26（2013）年以降参加者数 が減少傾向にあることがわかった。しかし「希望実施回 数」や「参加費」,「満足度」の結果, そして献立に対す る意見の分析から, 参加者数増加に対するヒントが得ら れた。例えば，参加者募集のチラシに教室の様子や評判 の良かった献立名の記載を加えるなどといったことが考 えられた。

「食意識の変化の有無」では「あり」と回答した者の割 合が高く，「参加の動機」の上位に『料理技術の習得』と 回答した者が多いことから料理に対する積極性が背景に あると考えられた。また講座の内容に調理実習のみでな く, 各コースでのテーマ（表1・2）に沿った講義を実 施したことが栄養に対する意識の変化を挙げた者が15名 という結果につながったと考えられた。

「参加の動機」では積極的な参加の動機である『料理技 術の習得』, 『基礎を学びたい』, 『料理に興味があった』 を合わせると 39 名と多くを占めた。これは, 参加者を対 象とした質問紙調査であることから当然の結果であると
考えられた。また『退職後の仲間づくり』も12名であ り，前向きにこれからの生活を過ごそうとしていると推 察された。『市報を見て』が 4 名と少なかったことから， 今後は募集に際して講座の様子の分かる写真などと一緒 に掲載する等, 工夫が必要ではないかと考えられた。さ らに，自主グループの活動をアピールすることで，仲間 づくりを期待する方々に参加のきっかけとなると考えら れた。

また今後も参加を希望する者が 21 名みられたことか ら, 今後はステップアップした中級編の開催も検討する 必要があると考えられた。「良かった献立」と「大変だっ た献立」の多くは共通した内容であったことから，参加 者にとって大変だったが充実感が得られたと推察され た。そのほかには，見た目がよく美味しくて簡単にでき る献立が好まれると推察され，今後の献立改定に参考に なると考えられた。また本講座は大根を使ったレシピを 組み込んでいるために自主グループ「だいこんの会」と 結び付くようになっているのが特徵である。『大根料理』 は平成23（2011）年度まで第 1 回で実施していたが，平 成24（2012）年から第 4 回の献立に移動した。これは前 
任者から引き継ぎの際，公社側担当者との打ち合わせ で, 初回に行うには料理初心者に負担が大きいという意 見が出たためである。しかし今回の分析結果から, 直近 の 5 年間の質問紙回答者 38 人中 『大根料理』に家庭で取 り組んだ者は 4 名という結果だった。『大根料理』のもう 一つの課題は, ここで取り上げている『大根の甘酢づけ』 のレシピで食塩を多く使用することである（表 2 ）。参加 者が高齢者男性であることを踏まえると, 厚生労働省が 平成26（2013）年に公表した「健康な食事」12）に示した ように, 1 食当たりの食塩相当量 $2.5 \mathrm{~g}$ 以下を目指す工 夫が必要であると考えられた。

今後, さらに参加者のニーズを把握したうえで, 食の 自立へと繋がる献立の改定の必要性が明らかになった。 とくに，日常生活における実践へと繋がる献立の工夫が 必要であると考えられた。

\section{V. 結 論}

東京都下で運営されてきた高齢者男性向けの料理教室 においる質問紙調查結果を分析した結果, 参加の動機か らみて積極的な参加者が多く, 献立も大変だが充実感の あるものを望んでいると考えられた。また半数近くが家 庭での調理を行っており，料理や調理技術への興味が高 まったことが推察された。高齢者男性向けの料理講座は 参加者にとって食の自立へつながる可能性が示唆された。

\section{謝 辞}

今回質問紙調査にご協力頂いた講座受講者の皆さん, 「だいこんの会」の方々, 本講座の講師を前任された栄養 士 ・大城英世氏に，また日本栄養改善学会関東 - 甲信越 支部の実践栄養学研究セミナーの先生方に心から感謝い たします。

\section{利益相反}

利益相反に相当する事項は無い。
文献

1）国立社会保障 - 人口問題研究所 : 日本の将来推計人口 （平成29年推計）報告書，人口問題研究資料第336号 平 成29年 7 月31日 (2017)

2）厚生労働省：平成28年 国民生活基礎調查の概況, https://www.mhlw.go.jp/toukei/saikin/hw/k-tyosa/ k-tyosa16/dl/16.pdf（2019年 7 月30日）

3）瀬戸美江, 塩谷知華, 澤田崇子, 他 : 世帯構成の違い が高齢者の食生活に及ぼす影響, 日本調理科学会誌, 40 , 15-21 (2007)

4）武山清子, 鈴木道子：一人暮らし後期高齢者の食生活 を支える諸要因，栄養学雑誌， 71, 112-119（2013）

5）河野あゆみ, 田高悦子, 岡本双美子, 他：大都市に住 む一人暮らし男性高齢者のセルフケアを確立するための 課題 高層住宅地域と近郊農村地域間の質的分析, 日本 公衆衛生雑誌, 56, 662-673 (2009)

6）内閣府: 第 3 次食育推進基本計画, http://warp.da.ndl. go.jp/info:ndljp/pid/9929094/www8.cao.go.jp/syokuiku/ about/plan/pdf/3kihonkeikaku.pdf（2018年 1 月 7 日）

7）東京都：東京都食育推進計画（平成28年度～平成32年 度), http://www.sangyo-rodo.metro.tokyo.jp/plan/nourin/ 76978b0a13e6bcalcla847daf29a1921.pdf（2018年 4 月 18 日）

8）野山 修：高齢期の健康な食生活を目指して，杏林医 会誌, 45, 111-113 (2014)

9）川烟輝子, 武見ゆかり, 村山洋史, 他 : 地域在住高歯 者に対する虚弱予防教室による虚弱および食習慣の改善 効果, 日本公衆衛生雑誌，62,169-181（2015）

10）森 圭子, 加藤友佳, 朽名宏恵, 他：地域自立高齢者 の栄養改善と Quality of Life, 愛知学院大学心身科学部紀 要, 4, 75-81 (2008)

11）文部科学省 科学技術 - 学術審議会 資源調查分科会 編：日本標準食品成分表2015（七訂）（2015）

12）厚生労働省：日本人の長寿を支える「健康な食事」の あり方に関する検討会報告書, https://www.mhlw.go.jp/ file/05-Shingikai-10901000-Kenkoukyoku-Soumuka/ 0000070498.pdf（2018年 1 月 7 日）

(受付：2019年 1 月16日，受理：2019年 7 月16日) 


\title{
Attitudes and Behaviors Regarding Eating among Participants in the "Cooking Courses for Men"
}

\author{
Yukiko Saito*1, Sinju Takeyasu*2, Masafumi Oikawa*2 and Hidemi Takimoto*1 \\ ${ }^{* 1}$ National Institute of Health and Nutrition, National Institutes of Biomedical Innovation, \\ Health and Nutrition \\ ${ }^{* 2}$ Chofu Yu-ai Welfare Public Corporation
}

\begin{abstract}
Objective: To improve the "Cooking Courses for Men," which have been conducted for men for over 20 years in the suburbs of Tokyo, we conducted a questionnaire survey to determine the food attitudes and behaviors of participants.

Methods: The "Cooking Courses for Men" was a living care prevention course series sponsored by the C Welfare Public Corporation from 2007 to 2016. We analyzed the results of 87 men aged 50 years or over who answered a questionnaire administered at the end of the course. The course consisted of nutrition lectures and cooking lessons, which were delivered 5 times a year. The questionnaire was used to collect data on reasons for participation, cooking at home, menus, change in food attitudes, course satisfaction, and number of lessons.

Results: To acquire cooking skills (28 participants) and to make friends after retirement (12 participants) were frequently cited as reasons for participation. Menus that were described as good and difficult were quite similar, and 45 tried to cook the menu at home. Fifty-four participants answered that their feelings toward eating changed after participation. These changes occurred in such areas as interest in cooking, cooking techniques, and feelings toward cooking. Sixty-three participants were satisfied with the course.

Conclusions: Most participants were highly motivated and wanted to try a difficult but satisfying menu. The survey results revealed that nearly half of the participants had cooked at home, and their interest in cooking and cooking techniques increased. A cooking course for middle-aged to elderly men may enable its participants to acquire skills to prepare food by themselves.
\end{abstract}

Jpn. J. Nutr. Diet., 77 (5) 123〜132 (2019)

Key words: elderly men, cooking courses, food knowledge and skills, independent living 